\title{
Application of Geophysical Method to detect the Subsurface Environment Parameter
}

\author{
$1^{\text {st }}$ Sutrisno ${ }^{1}, 2^{\text {nd }}$ Hety Nurbaity ${ }^{1}$ \\ \{sutrisno@uinjkt.ac.id ${ }^{1}$ \} \\ UIN Syarif Hidayatullah, Department of Physics, Jakarta, Indonesia ${ }^{1}$
}

\begin{abstract}
The subsurface environment is one important part of human life. People need the clean water from subsurface to fulfill their life. Therefore one needs to know the subsurface area that is free of contaminants to find sources of clean water. Geo electric is one geophysical method can be used to detect the clean water sources. Geo electric investigation done on the basis of the physical property of rock to electrical current. If the flow of direct current into the earth through the electrode currents A and B, then the measured potential difference caused by the current on 2 pieces of electrode potential on $\mathrm{M}$ and $\mathrm{N}$, it will obtain the value of resistivity pseudo types. Electrode configuration used in the form of Schlumberger configuration to determine the subsurface clean water aquiver. Interpretation of the results of the formation resistivity shows four layers of formation, which consists of layer 1 with the resistivity of 117-1978 ohm meter (conglomerate), layer 2 with the resistivity of 23-93 ohmmeter (sandstone 2), layer 3 with the resistivity of 1-10 ohmmeter (clay), and layer 4 with the resistivity $17-65 \mathrm{ohm}$ meter (sandstone 1). The possibility of formation that could serve as clean water reservoirs are sandstone1 and sandstone 2.
\end{abstract}

Keywords: Geo electric; sanitation, clean water, human life, resistivity

\section{Introduction}

In the last decade there has been a growth in population very rapidly in the world, it can lead to exploitation of groundwater continued to increase rapidly. This phenomenon has led to impacts negatively affect the quantity and quality of groundwater, including subsidence

in the groundwater, the groundwater quality degradation, and occurrence of sea water intrusion in some areas. Groundwater is a renewable natural resource currently has played an important role in providing water supply needs for a variety of purposes, so it is causing a shift in the value of the groundwater itself. Both individuals and community groups need water for daily and other needs. From a variety of those needs, then water for drinking is top priority, than all other purposes. This means that the function of water drinking should be pursued as well as possible in order to meet the requirements quality and quantity, as well as the best use for the needs of living things. Given the increasingly important role of groundwater, then utilization of groundwater in should be based on the balance and groundwater sustainability itself, or in other words the use of water land in environmentally sound and should be sustainable. The need for clean water can be overcome by using 
groundwater sources. Groundwater is water contained in the permeable layer, the water trapped in the cavities between the molecules of rocks, and the water can not come out by itself because it is very deep below the earth's surface. Layer containing water is more commonly called aquifers. Water shortages in some caused by the limited areas where aquifers are typically shaped layers. East Suwawal Village has choosen as the study area because this Village will be developed as a center pilot development of technology by all development agencies both national and local technology called " Kampung Technology ". "Kampung technology" will be developed as technology areas are divided into three regions, namely echopark, technopark, and agrotek area. The third region is very need a good supply of clean water for agriculture (irrigation) and land development of other technologies that require water to be kept continuously throughout the year.

\section{Methods}

Conside a single point electrodes which are at the limit of semi-infinite media, fictional homogeneous earth represented by electrically homogeneous. If the current I is transported by the electrode, and is calculated in amperes (a), then the potential that is at each point in the media or at the limit will be given by [1]:

$$
U=\rho \frac{I}{2 \pi r},
$$

where : $U=$ potential, in $V, \rho=$ resistivity of the medium, $r=$ distance from the electrode.

In geophysical books such as Keller and Frischknecht (1996) there are mathematical demonstrations that are used as derivations. in the pair between the electrode with the current I at the A electrode, and -I at the B electrode (figure 1), the potential at a point is obtained from the algebraic number and individual contribution [1]:

$$
U=\frac{\rho I}{2 \pi r_{A}}-\frac{\rho I}{2 \pi r_{B}}=\frac{\rho I}{2 \pi}\left[\frac{1}{r_{A}}-\frac{1}{r_{B}}\right],
$$

where : $r A$ and $r B=$ distances from the point to electrodes $A$ and $B$. Figure 1 illustrates the electric field around the two electrodes in terms of equipotentials and current lines. 


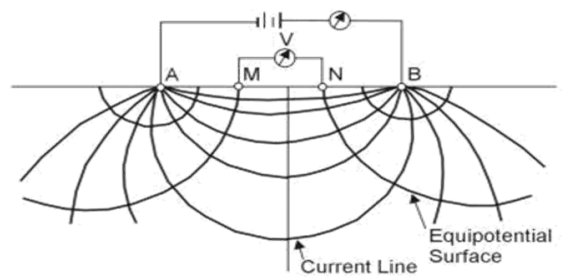

Figure 1. Equipotentials and current lines for a pair of current electrodes $\mathrm{A}$ and $\mathrm{B}$ on a homogeneous half-space [2].

Following the previous equation, the potential difference $V$ may be written [3] :

$$
V=U_{M}-U_{N}=\frac{\rho I}{2 \pi}\left[\frac{1}{A M}-\frac{1}{B M}+\frac{1}{B N}-\frac{1}{A N}\right],
$$

Where : $U M$ and $U N=$ potentials at $M$ and $N, A M=$ distance between electrodes $A$ and $M$.

The quantity is denoted $1 / K$, which allows rewriting the equation as:

$$
V=\frac{\rho I}{2 \pi} \frac{1}{K},
$$

Where $K=$ array geometric factor. Equation above can be solved for $\rho$ to obtain:

$$
\rho=2 \pi K \frac{V}{I},
$$

The resistivity of the medium can be found from measured values of $V, I$, and $K$, the geometric factor. $K$ is a function only of the geometry of the electrode arrangement. the ratio $\mathrm{s}$ to a is limited by the sensitivity of the instrument and stored in the boundaries of about 3 to 30. that is to use the distance of the electrode which is restricted and equation 2 to find the geometric factor value $(\mathrm{K})$. Resistivity can be explained as follows [3]:

$$
\rho_{a}=\pi\left[\frac{s^{2}}{a}-\frac{a}{4}\right] \frac{V}{I}=\pi a\left[\left(\frac{s}{a}\right)^{2}-\frac{1}{4}\right] \frac{V}{I},
$$

In usual field operations, the inner (potential) electrodes remain fixed, while the outer (current) electrodes are adjusted to vary the distance $s$. Also, the $a$ spacing may sometimes be adjusted with $s$ held constant in order to detect the presence of local inhomogeneities or lateral changes in the neighborhood of the potential electrodes. This array consists of four electrodes in line, separated by equal intervals, denoted $a$. Applying equation above, it will find that the geometric factor $\mathrm{K}$ is equal to $a$, so the apparent resistivity is given by [3]:

$$
\rho_{a}=\pi\left[\frac{s^{2}}{a}-\frac{a}{4}\right] \frac{V}{I}=\pi a\left[\left(\frac{s}{a}\right)^{2}-\frac{1}{4}\right] \frac{V}{I},
$$


Although the Schlumberger array has always been the favored array in Europe, until recently, the Wenner array was used more extensively than the Schlumberger array in the United States.

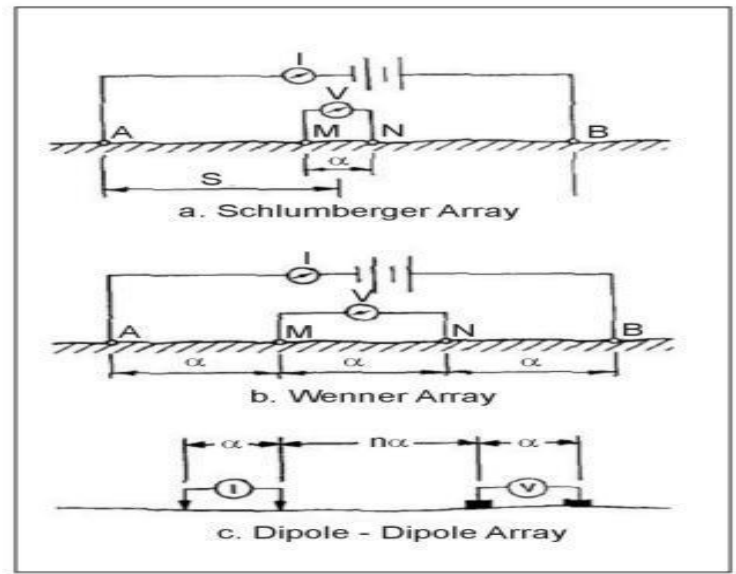

Figure 2. Electrode array configurations for resistivity measurements [3].

The dipole-dipole array (figure $2 \mathrm{c}$ ) is one member of a family of arrays using dipoles (closely spaced electrode pairs) to measure the curvature of the potential field. If the separation between both pairs of electrodes is the same $a$, and the separation between the centers of the dipoles is restricted to $a(n+1)$, the apparent resistivity is given by [3]:

$$
\rho_{a}=\operatorname{\pi an}(n+1)(n+2) \frac{V}{I},
$$

From the coordinate data obtained is then processed with software Mapinfo 8.5 to obtain the position of the map corresponding to the map East Suwawal Village topography.

Apparent resistivity data is read by the tools used to determine rho and depth that is by entering the value $\mathrm{AB} / 2, \mathrm{MN}$ and value pseudo rho, using the software IX1D be obtained rho value, depth, thickness, and elevation automatically $[5,6]$. In the following order: Opening IX1D program, then select the menu File New Sounding Resistivity / IP Sounding Determination of the cross-correlation Once known rho prices and depth of each point sounding then performed. This correlation is done for determine the form, distribution, thickness, and depth of rock layers. We use CorelDraw 12 software.

\subsection{Data Collection Method}

In compiling this thesis the writer will use the data collection method as follows:

a) Interviews

This method is done by conducting interviews to parts and Utilization Program Baitul Maal Hidayatullah, Mr Ade Syariful Allam regarding related problems. This is done in order to obtain complete information - details about the distribution of zakat funds terhdap Mustahik in Baitul Maal Hidayatullah as acauan in conducting this research. In this interview there are some questions about the assessment process for the selection of Mustahik ongoing and expected solution. The timing of the interviews were conducted at :

$\begin{array}{ll}\text { Place } & : \text { Baitul Maal Hidayatullah } \\ \text { Day } & : \text { Tuesday } \\ \text { Date } & : 5 \text { April } 2016\end{array}$




\section{Addressed : Bapak Ade Syariful Allam \\ Title : Director of Programs and Reforms}

b) Study Library

Researchers to study literature by reading and studying books related to the analysis and design of Decision Support Systems (DSS), web programming as well as books that support the method of Weighted Product and waterfall system development methods discussed in the preparation of this thesis. There are several books that may be referenced in this thesis sunan turtles and for a list of books - books can be seen on the bibliography.

\section{Results and Discussions}

Geologically, East Suwawal Village, Pakis Aji District, Jepara including the area with the plain waved morphology, which is composed of some formations such as tuff and Muria alluvium. East Suwawal village is one of the villages in the Jepara regency. East Suwawal village is the village which is quite extensive, there are lands owned Perusda Jepara regency. Seen from topographic maps, this village is at the height of the lowest elevation of $30 \mathrm{~m}$ above sea level and $72 \mathrm{M}$ of the highest sea level with a maximum height difference of $42 \mathrm{~m}$. The maximum slope of 5.50 that is included in the area with undulating terrain morphology, as in the image below. Based on the geological interpretation of the results is known that the village Suwawal The east composed of several formations including; Tuff Muria and Alluvium [7].

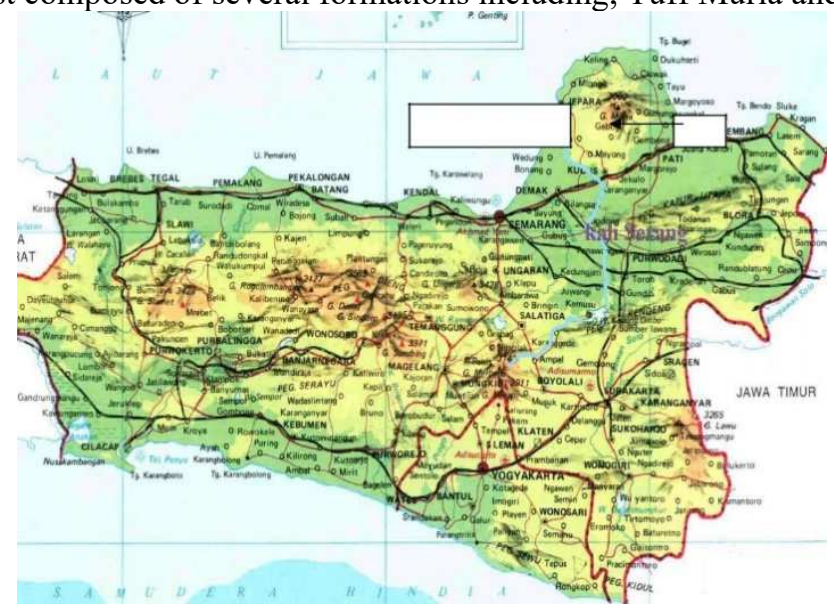

Figure 3. Province of Central Java and area of research [7]

Muria composed by tuff tuff, lava and sandy tuff. tuff color yellow to brown, poorly plated, pebble -grained lapilli up, less compact, partially weathered and brittle. Berkomponen lava fragments leusit rock - teprit, leusitit, basalt, andesite and trakit, local limestone and rocks trubah with future volcanic sand bottom, and structure intermittent stream. Sandy to clay sized tuff lapilli up subtle, layered stacking structure as inserts in the tuff. Lithologies has spread quite widely. The estimated age of rock units together with Lava Muria, the Pleistocene - Holocene. Alluvium is composed by gravel, sand, clay, silt, remnant vegetation and boulders of rock mountain fire in the form of beach sediments, wetlands, and rivers. Sounding data processing has been done before, stages. The first correction to the data 
obtained resistivity East Suwawal Village. The data is processed to obtain the 1D models by the IX1D software. At this process the result showed in the following table with the format of layer, rho value, kind of layer, height, and depth [8,9]:

Table 1. The Cross Section Correlation For Track 1

\begin{tabular}{|c|c|c|c|c|c|}
\hline Layer & & Rho Value & Kind Of Layer & Height & Thickness \\
\hline Layer 1 & 15 & -1400 Ohm.M & Conglomerat & $68-72$ & $4 \mathrm{M}$ \\
\hline Layer 2 & 90 & 900 Ohm.M & Conglomerat & $59-68 \mathrm{M}$ & $9 \mathrm{M}$ \\
\hline Layer 3 & 2 & 42 Ohm.M & Sand & $13-59 \mathrm{M}$ & $46 \mathrm{M}$ \\
\hline Layer 4 & & 10 Ohm.M & Clay & $4-13 M$ & $17 \mathrm{M}$ \\
\hline
\end{tabular}

Table 2. The Cross Section Correlation For Track 2

\begin{tabular}{lrrlll}
\hline \multicolumn{1}{l}{ Layer } & & Rho Value & Kind of Layer & Height & Thickness \\
\hline Layer 1 & 87 & & & \\
& & & & \\
Layer 2 & 20 & 557 ohm.m & Conglomerat & $46-58 \mathrm{~m}$ & $12 \mathrm{~m}$ \\
Layer 3 & 7 & 86 ohm.m & Sand 2 & $15-46 \mathrm{~m}$ & $31 \mathrm{~m}$ \\
Layer 4 & & 8 ohm.m & Clay & $1-15 \mathrm{~m}$ & $29 \mathrm{~m}$ \\
\hline
\end{tabular}

Table 3. The Cross Section Correlation For Track 3

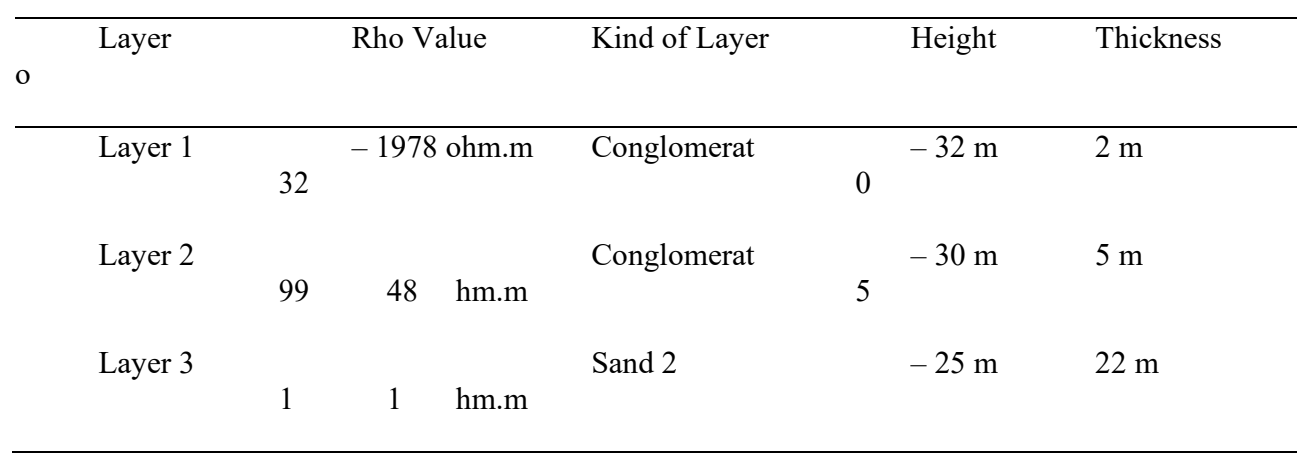




\begin{tabular}{lllllll}
\hline Layer 4 & 7 & 5 & hm.m & Sand 1 & $-3 \mathrm{~m}$ & $37 \mathrm{~m}$ \\
& & & & & \\
\hline
\end{tabular}

Table 4. The Cross Section Correlation For Track 4

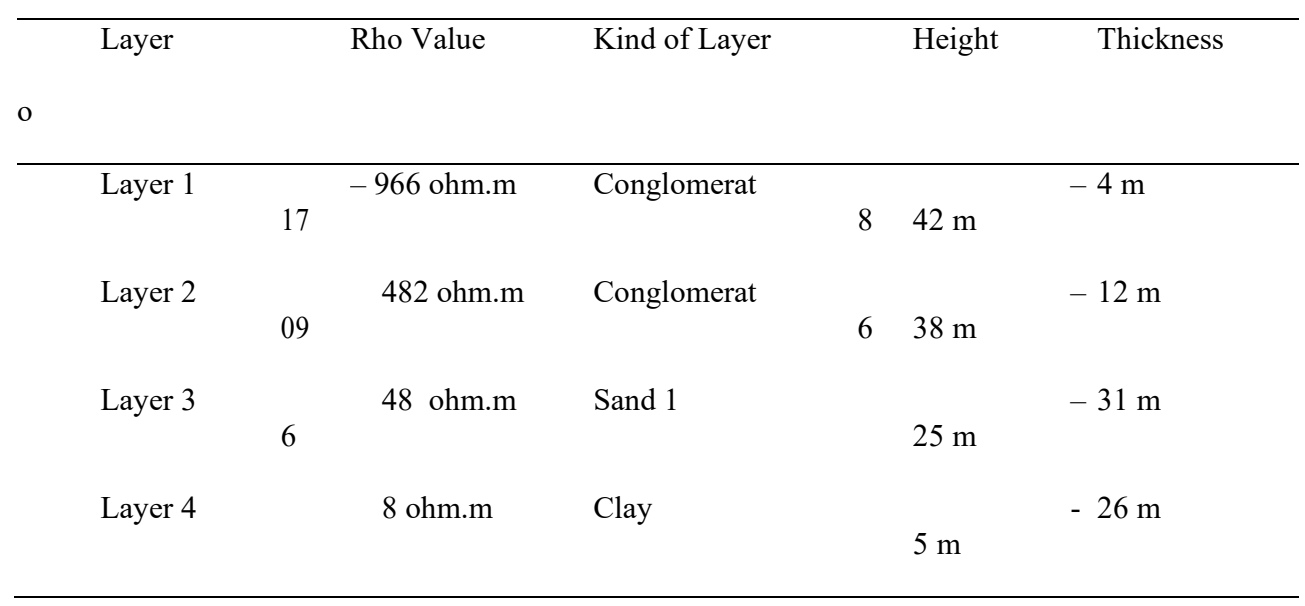

The next stage is to create a 2D model using CorelDraw 12 software. This $2 \mathrm{D}$ model by correlating rho and depth values obtained from the data processing previously. Then made a trajectory drawn by hand straight line either horizontally, vertically, or diagonally on the points adjacent, is shown in figure 4 for model cross section track 1 , figure 5 for model cross section track2, figure 6 for model cross section track 3, and figure 7 for the model cross section track 4 . All of the models showed on the following figure:

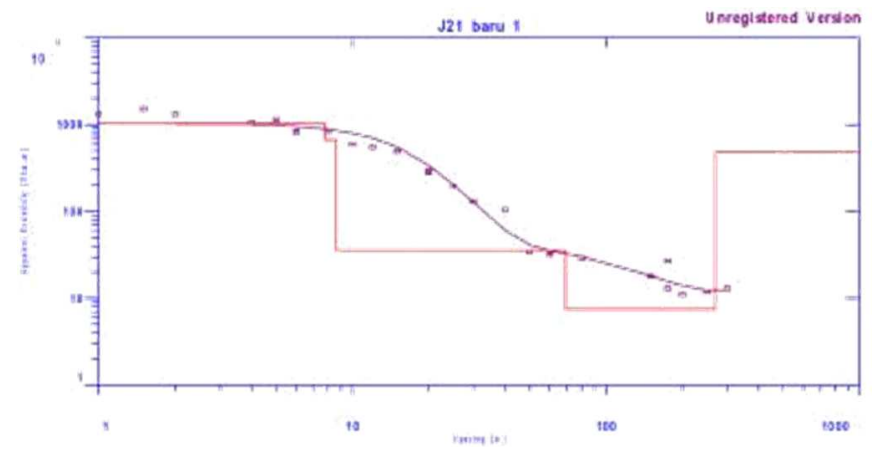

Figure 4. The model cross section of track 1 


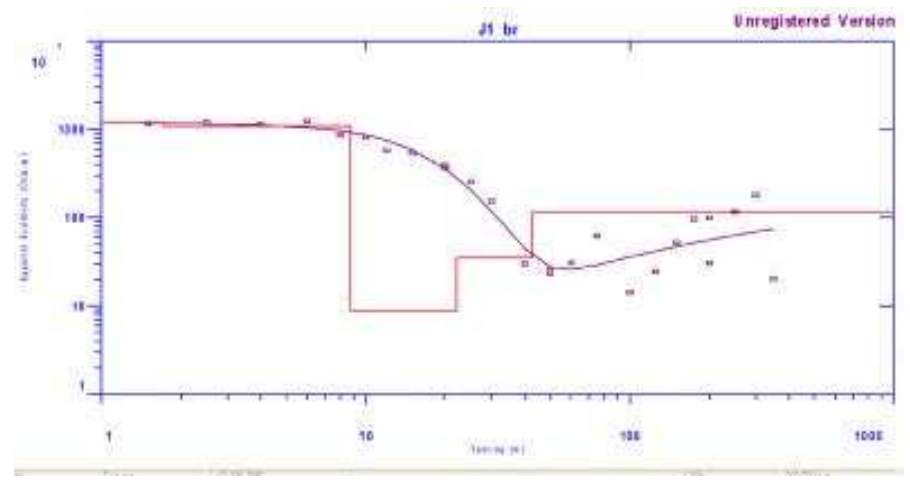

Figure 5. The model cross section of track 2

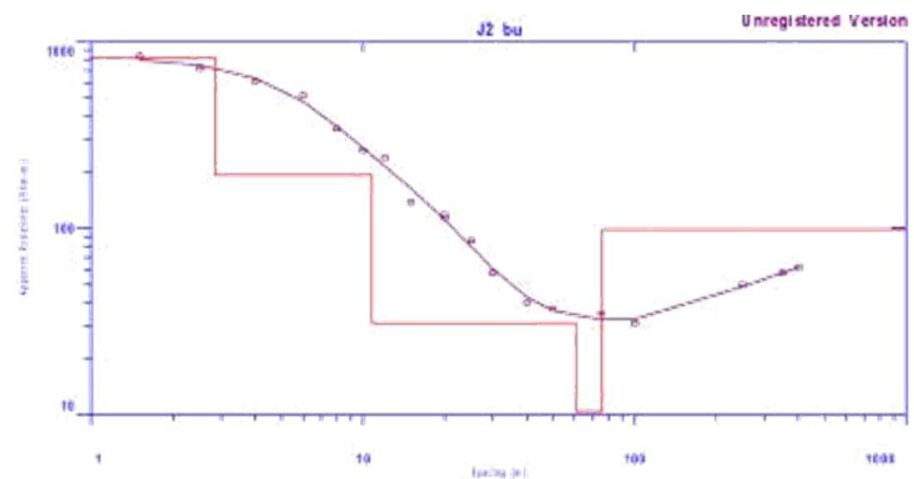

Figure 6. The model cross section of track 3

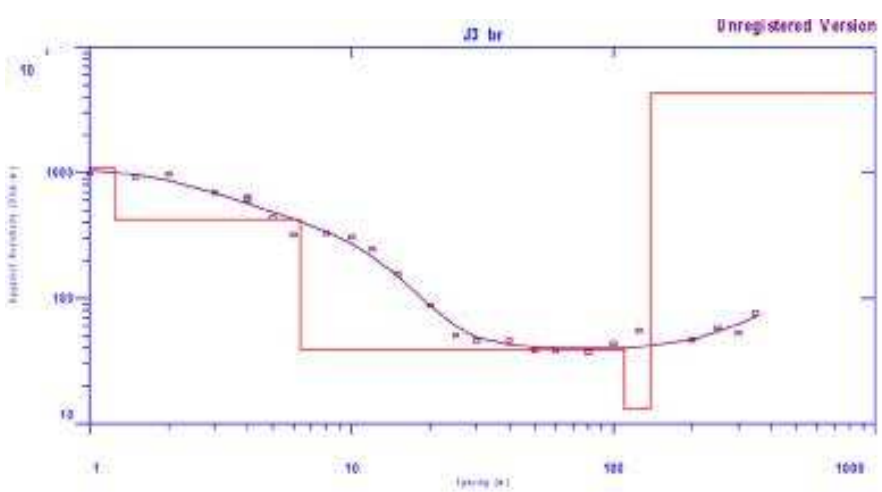

Figure 7. The model cross section of track 4 
The last step is to determine the elevation value of subsurface clean water flow direction. Based on the determination of the cross section-correlation of the above there are four models cross section track. Cross section tracks 1 consist of 4 layers of 2 layers of conglomerate, 1 layers of sandstone, and one layer of clay. Cross section tracks 2 consist of 4 layers of 2 layers of conglomerate, 1 layers of sandstone 2, and one layer of clay. Cross section tracks 3 consist of 4 layers of 2 layers of conglomerate, 1 layers of sandstone 2, and one layer of sandstone 1 . Cross section tracks 4 consist of 4 layers of 2 layers of conglomerate, 1 layers of sandstone 1, and one layer of clay. Found in sandstone that is at a height of 13-59 $\mathrm{m}$ and the value of resistivity between $22-42 \mathrm{ohm}-\mathrm{m}$. Soundings taken four points since adapted to the conditions territory uneven and bumpy. Clay layer having distorting sounding point slightly upwards which influenced by structural and morphological state at this point. This trajectory flow is relatively towards the north direction.

\section{Conclusion}

Based on the results of geoelectric data processing concluded as follows, there are four location of aquifers, namely:

1. Tracks 1: found in the sandstone aquifer which is at depth of $13-59 \mathrm{~m}$ and resistivity values $22-42 \mathrm{ohm} \mathrm{m}$.

2. Track 2: The aquifers are found in 2 layers of them on the rocks sand 1 is located at a depth $(-50)-(-14) \mathrm{m}$ with value resistivity $17-35 \mathrm{ohm} \mathrm{m}$ and sandstone 2 which is at depth of 15-46 $\mathrm{m}$ with a price resistivity $37-86 \mathrm{ohm}-\mathrm{m}$

3. Track 3: aquifer on this track are the sandstone layer 1 is located at a depth $(-40)-3$ $\mathrm{m}$ and resistivity value $41-71 \mathrm{ohm}-\mathrm{m}$, and 2 sandstone is at a depth of 3-25 $\mathrm{m}$ and value resistivity $17-65 \mathrm{ohm}$

4. Tracks 4: aquifer on this track are the sandstone layer 1 and 2 layers of sandstone. At 1 sandstone is at a depth $(-75)-(-31) \mathrm{M}$ with a value resistivity $16-95 \mathrm{ohm}-\mathrm{m}$, while the sandstone is at a depth of $2(-5)-26 \mathrm{~m}$ the price of resistivity $36-48 \mathrm{ohm}-\mathrm{m}$.

Direction of groundwater flow in the aquifer for the top and bottom relative to the north.

\section{References}

[1] Telford, W. M. dkk. Applied Geophysics, 2nd ed. Cambridge University Press, 1990.

[2] JS Sumner, Principles of Induced Polarization for Geophysical Exploration, Elsevier Scientific Publishing Company, Amsterdam, Oxford, New York, 1976.

[3] Richard Van Blaricom, Practical Geophysics, Northwest Mining Association.

[4] Anonim. Model Kursus Geolistrik Aplikasi Geolistrik Sounding Dalam Eksplorsi Air Tanah dan Sistem Panas Bumi. Yogyakarta: Fakultas Matematika dan Ilmu Pengetahuan Alam Universitas Gajah Mada.

[5] Dwiningsih, Nunung Isnaini. Modul Praktikum Magnetik. Pusat Laboratorium Terpadu, Universitas Islam Negeri Syarif Hidayatullah Jakarta, 2004.

[6] Hendrayana, Heru. Intrusi Air Asin Ke Dalam Akuifer Di Daratan.

[7] Jogyakarta: Universitas Gajah Mada. 2002.

[8] Sapiie, Benyamin. dkk. Catatan Kuliah GL-1211 Geologi Fisik. Bandung: ITB. 2006. 
[9] Mardiana, Undang. Nilai Tahanan Jenis Batuan Daerah Mataair Desa Saba Kecamatan Blah Batuh Kabupaten Gianyar Provinsi Bali. Bandung: Universitas Padjadjaran. 2006.

[10] Megawati, Ikeu. Identifikasi Airtanah Dalam (Akuifer) Di Desa Demak Berdasarkan Data Tahanan Jenis. Jakarta: UIN Syarif Hidayatullah. 2008.

[11] Rosid, Syamsu dan Johan Muhamad. PemetaanHidrogeologi Dengan Menggunakan Metode Geolistrik. Jakarta: Departemen Fisika FMIPA Universitas Indonesia. 2008 